\title{
Review \\ Contribution of "Omic" Studies to the Understanding of Cadasil. A Systematic Review
}

\author{
Elena Muiño ${ }^{1,+}{ }^{\prime}$ Israel Fernández-Cadenas ${ }^{1, *,+}$ and Adrià Arboix ${ }^{2, *(1)}$ \\ 1 Stroke Pharmacogenomics and Genetics Group, Institut de Recerca de l'Hospital de la Santa Creu i Sant Pau, \\ 08041 Barcelona, Spain; elena.muinho@gmail.com \\ 2 Cerebrovascular Division, Department of Neurology, Hospital Universitari del Sagrat Cor, \\ Universitat de Barcelona, 08007 Barcelona, Spain \\ * Correspondence: israelcadenas@yahoo.es (I.F.-C.); aarboix@quironsalud.es (A.A.); Tel.: +34-93-4948940 (A.A.); \\ Fax: +34-93-4948906 (A.A.) \\ + E.M. and I.F.-C. contributed equally to this work.
}

Citation: Muiño, E.

Fernández-Cadenas, I.; Arboix, A. Contribution of "Omic" Studies to the Understanding of Cadasil. A Systematic Review. Int. J. Mol. Sci. 2021, 22, 7357. https://doi.org/ $10.3390 /$ ijms 22147357

Academic Editors: Mario Costa and Eleonora Vannini

Received: 27 May 2021

Accepted: 5 July 2021

Published: 8 July 2021

Publisher's Note: MDPI stays neutral with regard to jurisdictional claims in published maps and institutional affiliations.

Copyright: (c) 2021 by the authors. Licensee MDPI, Basel, Switzerland. This article is an open access article distributed under the terms and conditions of the Creative Commons Attribution (CC BY) license (https:// creativecommons.org/licenses/by/ $4.0 /)$.

\begin{abstract}
CADASIL (Cerebral Autosomal Dominant Arteriopathy with Subcortical Infarcts and Leukoencephalopathy) is a small vessel disease caused by mutations in NOTCH3 that lead to an odd number of cysteines in the epidermal growth factor (EGF)-like repeat domain, causing protein misfolding and aggregation. The main symptoms are migraines, psychiatric disorders, recurrent strokes, and dementia. Omic technologies allow the massive study of different molecules for understanding diseases in a non-biased manner or even for discovering targets and their possible treatments. We analyzed the progress in understanding CADASIL that has been made possible by omics sciences. For this purpose, we included studies that focused on CADASIL and used omics techniques, searching bibliographic resources, such as PubMed. We excluded studies with other phenotypes, such as migraine or leukodystrophies. A total of 18 articles were reviewed. Due to the high prevalence of NOTCH3 mutations considered pathogenic to date in genomic repositories, one can ask whether all of them produce CADASIL, different degrees of the disease, or whether they are just a risk factor for small vessel disease. Besides, proteomics and transcriptomics studies found that the molecules that are significantly altered in CADASIL are mainly related to cell adhesion, the cytoskeleton or extracellular matrix components, misfolding control, autophagia, angiogenesis, or the transforming growth factor $\beta$ (TGF $\beta$ ) signaling pathway. The omics studies performed on CADASIL have been useful for understanding the biological mechanisms and could be key factors for finding potential drug targets.
\end{abstract}

Keywords: CADASIL; genomic; transcriptomic; proteomic

\section{Introduction}

CADASIL (Cerebral Autosomal Dominant Arteriopathy with Subcortical Infarcts and Leukoencephalopathy; OMIM\#125310) is a systemic arteriopathy of non-atherosclerotic and non-amyloid cause. It is a rare disease affecting fewer than 2/1000 individuals, caused by mutations in the NOTCH3 gene. It has autosomal dominant inheritance, although it can also occur due to de novo mutations [1].

The etiopathogenesis of the disease is not well understood. It is thought to be triggered by mutations in NOTCH3 that cause an odd number of cysteines in the domain hosting the epidermal growth factor-like repetitions (EGFr) of the receptor encoded by this gene, leading to disruption of disulfide bonds and protein aggregation [2,3].

CADASIL is characterized by the following symptoms: migraine with aura; psychiatric disorders; recurrent small subcortical infarcts; and dementia at an early age [4]. It is the most common cause of stroke and dementia of genetic origin. On MRI scans, white matter hyperintensities (WMH) in the temporal lobe and external capsule are characteristic of the disease $[5,6]$. 
The presence of protein aggregates known as granular osmiophilic material (GOMs) in skin biopsies of patients, assessed by electron microscopy, has $100 \%$ specificity for its diagnosis [5]. However, due to the focal nature of GOMs, false negatives may occur [7]. Therefore, the definitive diagnosis is established through genetic testing with the identification of pathogenic mutations, which affect the number of cysteines in EGFr.

Once the diagnosis has been made, it is difficult to determine the patients' clinical course. Patients can progress differently, even if they have the same mutation, belong to the same family, or even if they are monozygotic twins [8,9].

There is no curative or disease-modifying treatment, only symptomatic treatments are available. Hence the importance of deepening our understanding of the disease in order to find therapeutic targets whose modulation can improve the quality of life of these patients.

Omic technologies are used to detect genes (genomics), mRNA (transcriptomics), proteins (proteomics), and metabolites (metabolomics) in a specific biological sample in a non-targeted and non-biased manner. The integration of these techniques is called systems biology [10]. Unlike with traditional studies, with these techniques, it is possible to generate hypotheses, which are mostly driven or reductionist hypotheses [10].

Omic technologies can be used in screening, diagnosis, and prognosis, as well as for aiding our understanding of the etiology of diseases or identifying biomarkers [10,11]. Moreover, they are used in target [12] and drug discovery and in the assessment of their toxicity and efficacy [10].

With this review, we aim to take a closer look at the progress made in recent years in CADASIL thanks to omics technologies, as well as to explore what therapeutic possibilities these technologies could offer through a comprehensive resource for omics research on drugs, such as the DrugBank (https:/ / go.drugbank.com, accessed on 27 May 2021).

The use of omics technologies in the field of CADASIL allows for a more efficient diagnosis of the disease. From an epidemiological point of view, it has been found that in genomic repositories, there is a high prevalence of individuals with variants affecting the number of EGFr cysteines. This then raises the question of whether they all really are pathogenic mutations, which was previously considered to be the case. From an etiological point of view, the massive study of data has highlighted the importance of metabolic functions/pathways related to the extracellular matrix, cell adhesion, autophagy, misfolding control, angiogenesis, or TGF $\beta$ signaling. These technologies have allowed us to understand the histopathological findings in the disease or identify which molecules or pathways may be of interest for drug targeting, opening a wide range of possibilities for the development of future clinical trials.

\section{Materials and Methods}

We have conducted an exhaustive literature search up to April 2020 by one reviewer in PubMed, LILACS, Trip Database, and The Cochrane Library. The keywords used were: (CADASIL[Title/Abstract]) AND ((proteom*[Title/Abstract]) OR (tran-scriptom*[Title/ Abstract]) OR (genom*[Title/Abstract]) OR (gwas[Title/Abstract]) OR (integrom*[Title/ Abstract]) OR (metabolom*[Title/Abstract]) OR (microbio*[Title/Abstract])).

A total of 58 articles was listed in PubMed, zero in LILACS, 23 in Trip Database and one in The Cochrane Library. Fifty-six articles were excluded as they were not relevant to our study.

Twenty-six articles were screened and two more were sought for retrieval. Ten articles were excluded because the topic was not on CADASIL, and they focused on other phenotypes, such as migraine or leukodystrophies. Finally, we reviewed 18 studies (Figure 1). 


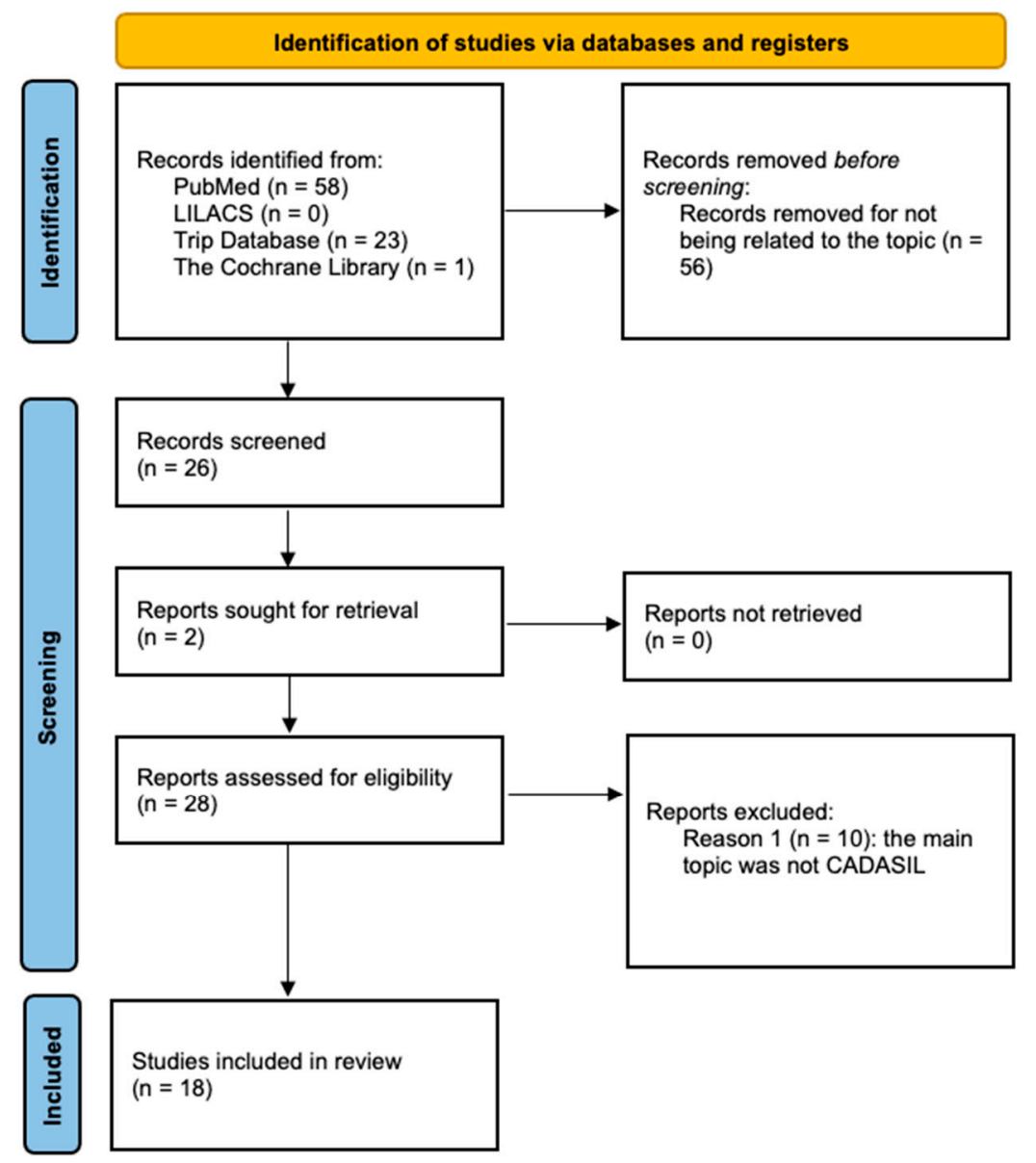

Figure 1. PRISMA flow diagram.

For the search for the GO molecular function and biological process we used Ensembl. We use DrugBank (https:/ / go.drugbank.com) to discover which potential drugs could interfere with the molecules obtained with omics technologies. DrugBank is a comprehensive resource for omics research on drugs. It offers drug-action pathways, drug transporter data, drug metabolite data, pharmacogenomic data, adverse drug response data, ADMET data, pharmacokinetic data, computed property data and chemical classification data.

\section{Genome-Wide Sequencing and Progress in Epidemiology}

The first efforts for detecting the true prevalence of CADASIL were made in 2005, with an attempt at estimating the minimum prevalence of this disease in the East of Scotland [13]. By studying exons 3, 4, 5, and 6 of the NOTCH3 gene or skin biopsies of patients with suspected CADASIL, the minimum prevalence was established at 1.98/100,000 adult individuals. In 2012, a similar low prevalence was confirmed in the North East of England $(1.32 / 100,000$ adults) [14]. Later studies found a minimum prevalence in Scotland and Central Italy that was almost twice as high: 4.1/100,000 adult individuals $[15,16]$.

With the improvement of technology that allows for the massive study of data, diagnosis of the disease has become more efficient. It is now possible to analyze the entire $\mathrm{NOTCH} 3$ gene in less time and at a lower cost, instead of studying only certain exons or even clinical exomes.

In fact, because of the creation of biobanks, which are projects that aggregate and harmonize exome and genome sequencing data from a wide variety of large-scale sequencing studies, it has been possible to further profile mutations affecting cysteine residues in Notch3 in a significant number of individuals. In the Genome Aggregation Database (gnomAD, http:/ / gnomad.broadinstitute.org, accessed on 27 May 2021), the UK Biobank (UKB, https: / / www.ukbiobank.ac.uk, accessed on 27 May 2021) and the Geisinger Dis- 
covEHR (http:/ / www.discovehrshare.com, accessed on 27 May 2021), a prevalence of 1.43.4/1000 subjects carrying NOTCH3 variants that were considered pathogenic were established [17-21] (Figure 2), and 9/1000 in the Taiwan Biobank (https: / / taiwanview.twbiobank.org.tw /index, accessed on 27 May 2021) [22], the latter high frequency is in line with the UKB observation of enrichment of pathogenic mutations in NOTCH3 in Asians [19].

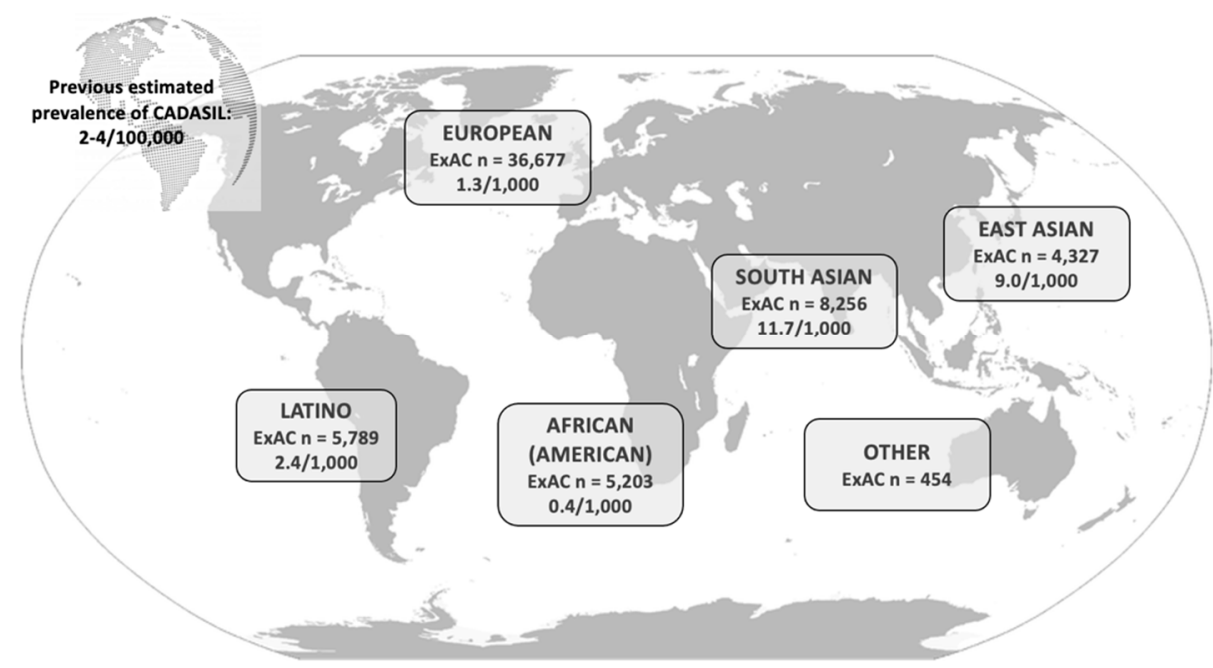

Figure 2. Graphical representation of the frequency of pathogenic CADASIL mutations according to the populations included in the ExAC database (currently called gnomAD). Figure adapted from Rutten et al. (2016) [17].

This progress led some authors to hypothesize that there may be paucisymptomatic phenotypes due to the different location of the mutations within the protein, as the profile of EGFr affected in patients diagnosed with CADASIL and population cohorts is different (Figure 3) [17-19].

NOTCH3 mutations reported in CADASIL worldwide

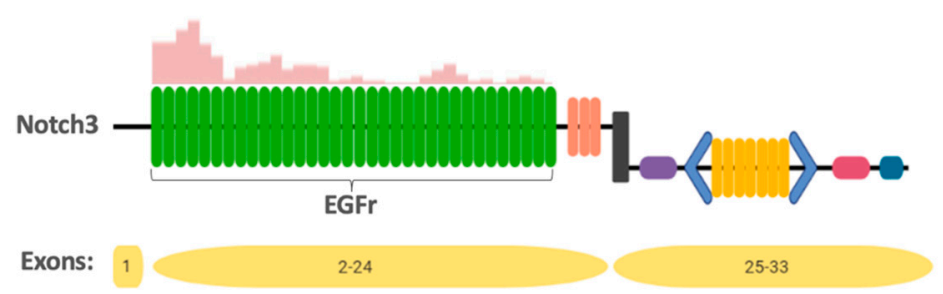

NOTCH3 mutations in EXAC

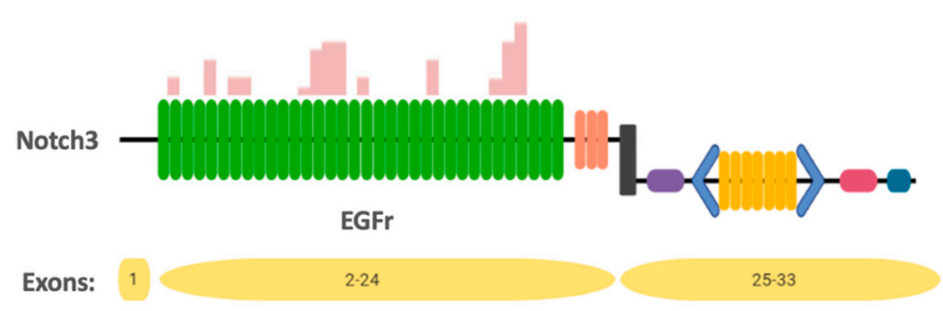

Figure 3. Distribution of different EGFr cysteine altering NOTCH3 mutations in ExAC (currently called gnomAD) compared with those reported in cerebral autosomal dominant arteriopathy with subcortical infarcts and leukoencephalopathy (CADASIL) patients. Figure adapted from Rutten et al. (2016) [17]. 


\section{Omic Studies and Progress in the Etiopathogenesis of CADASIL}

\subsection{Proteomic Studies and Progress in the Etiopathogenesis of CADASIL}

Multiple efforts have been made to try to understand the etiopathogenesis of this disease. The most widely accepted hypothesis was that the presence of an odd number of cysteines in the EGFr region leads to disruption of disulfide bonds and aggregation of the extracellular receptor domain (ECD) of both the Notch3 produced by the mutant allele and the Notch3 produced by the wild-type (WT) allele, as well as other proteins $[2,23]$. The formation of these complexes can be intracellular, at the plasma membrane of vascular smooth muscle cells (VSMCs) and pericytes [24,25], and extracellular in the so-called GOMs [26,27].

In the pre-omics era, most studies focused on the histological analysis and functional study of the receptor. It became clear that cellular adhesion to the extracellular matrix and between cells is disrupted, with degeneration and loss of endothelial cells, VSMCs, and pericytes [28-35], leading to altered autoregulation of blood flow and cerebral perfusion [31]. Besides, it has been recently postulated that there is an increase in Notch3 activity [36,37], hypothesizing that ECD aggregation could lead to aberrant Notch3 activation (independent of ligand binding).

On the other hand, only a few studies have explored other possible alterations that could influence the development of the disease. Some studies revealed that autophagy could be affected, as Notch3 accumulation is a possible indicator of autophagolysosomal pathway deficiency, as well as impaired intracellular trafficking and lysosomal maturation or defects [38]. Other studies showed the possibility of mitochondrial changes, as histological studies revealed mitochondrial morphological changes in VSMCs [33,39-41], or sporadic cases have shown altered mitochondrial respiratory chain complexes [42].

However, because of the omics sciences and genetic data repositories, it has become clear that there is a high prevalence of these types of mutation that are considered pathogenic, which may suggest that some are a risk factor for small vessel disease and that not all of them actually produce CADASIL [19-22]. On the other hand, if all of them do cause CADASIL, it should no longer be considered a rare disease.

In fact, the etiopathogenesis of the disease has been elucidated in more detail. ArboledaVelasquez et al. analyzed the tunica media of cerebral arteries from two CADASIL patients and two sex- and age-matched controls post-mortem [43]. Using laser capture microdissection and mass spectrometry (MS), they found 19 proteins differentially expressed in CADASIL vs. control samples (Table 1). When we searched Gene Ontology (GO), it became apparent that these 19 proteins were involved in cell adhesion processes, cytoskeleton or extracellular matrix components, misfolding control, and clearance. This finding is in line with histopathological alterations found in pathology studies and highlights other pathways of interest, such as autophagy.

Monet-Leprêtre et al. used nano-liquid chromatography-tandem MS to study human brain artery samples from one CADASIL patient and one healthy donor. They found 104 enriched proteins in the CADASIL sample, the majority of which was in the extracellular matrix proteins. The Notch3 ECD was almost undetectable in the control but vastly accumulated in the CADASIL sample [44]. Other molecules related to matrix metalloproteinases were found in proteomic experiments with animal models. Murine brain arteries of TghNotch3 (WT) and mutant transgenic TghNotch3 (R90C) mice were analyzed. Two proteins, TIMP3 (belonging to the TIMP family, which are metalloproteinase inhibitors) and vitronectin (VTN, a cell adhesion regulator, signaling cytoskeleton reorganization and extracellular matrix homeostasis $[44,45])$, were present in the mutant arteries and almost absent in the control arteries. Moreover, these proteins were strongly enriched in the human CADASIL sample experiment and were recruited into CADASIL deposits in vivo [44].

On the other hand, of the 19 proteins identified by Arboleda-Velasquez et al., 11 were analyzed by Monet-Leprêtre et al., supporting the previous results.

Zellner et al. performed a brain vessel proteome with MS with six CADASIL patients (carrying five different $\mathrm{NOTCH} 3$ mutations) and six age-matched neurologically healthy 
controls. Of the quantified proteins, 190 showed a raw $p$-value $<0.05$ [46]. Categorization of proteins according to subcellular localization (UniProt database) demonstrated a strong overrepresentation of extracellular space, secreted, and mitochondrial proteins. Most of the mitochondrial categories were depleted in the CADASIL group, and the majority of secreted and extracellular space proteins were enriched [46]. Notch3 exhibited the strongest increase in abundance, and multivariate analysis showed significance for Notch3 and 16 additional proteins with increased abundance [46] (Table 1).

Table 1. Proteomic analysis of human brain vessels. Proteins whose levels were different between patients with CADASIL and controls in the study by Arboleda-Velasquez et al. [43], Monet-Leprêtre et al. [44], and Nagatoshi et al. [47].

\begin{tabular}{|c|c|c|c|c|}
\hline Protein Name & $\begin{array}{l}\text { Change } \\
\text { AV }\end{array}$ & $\begin{array}{l}\text { Change } \\
\text { ML }\end{array}$ & $\begin{array}{l}\text { Change } \\
\mathrm{N}\end{array}$ & Molecular Functions and Biological Process \\
\hline $\begin{array}{c}\text { Annexin A2 pseudogene } \\
2[43]\end{array}$ & + & & & \\
\hline Clusterin [43] & + & + & & $\begin{array}{l}\text { Protein processing and vesicular traffic: response to misfolded } \\
\text { protein, chaperone-mediated protein folding, chaperone-mediated } \\
\text { protein complex assembly, ubiquitin protein ligase binding, negative } \\
\text { regulation of response to endoplasmic reticulum stress } \\
\text { Nervous system: regulation of neuron death, microglial cell } \\
\text { proliferation and activation, central nervous system myelin } \\
\text { maintenance } \\
\text { Proteins related to Alzheimer's disease: amyloid-beta binding, } \\
\text { regulation of amyloid-beta clearance and negative regulation of } \\
\text { amyloid-beta formation; tau protein binding, positive regulation of } \\
\text { tau-protein kinase activity, positive regulation of neurofibrillary tangle } \\
\text { assembly } \\
\text { Survival: negative regulation of intrinsic apoptotic signaling pathway } \\
\text { in response to DNA damage }\end{array}$ \\
\hline Collagen $12 \propto 1$ [43] & + & + & + & $\begin{array}{l}\text { Extracellular matrix: extracellular matrix structural constituent } \\
\text { conferring tensile strength } \\
\text { - Cell adhesion }\end{array}$ \\
\hline Collagen $14 \propto 1$ [43] & + & + & & $\begin{array}{l}\text { Extracellular matrix: extracellular matrix structural constituent } \\
\text { conferring tensile strength } \\
\text { Cell adhesion }\end{array}$ \\
\hline $\begin{array}{c}\text { Collagen } 18 \alpha 1 \\
\text { (endostatin included) } \\
{[43]}\end{array}$ & + & + & & $\begin{array}{l}\text { - } \quad \text { Extracellular matrix: extracellular matrix structural constituent } \\
\text { conferring tensile strength, extracellular matrix organization } \\
\text { - Cell adhesion } \\
\text { - } \quad \text { Blood and blood vessels: angiogenesis, endothelial cell } \\
\text { morphogenesis, response to hydrostatic pressure }\end{array}$ \\
\hline Collagen $1 \propto 2$ [43] & + & & & $\begin{array}{l}\text { Protein processing and vesicular traffic: rho protein signal } \\
\text { - } \quad \text { Extracellular matrix: collagen fibril organization, extracellular matrix } \\
\text { assembly } \\
\text { Blood and blood vessel: blood vessel development, regulation of } \\
\text { blood pressure, platelet-derived growth factor binding } \\
\text { - Smooth muscle: rho protein signal transduction } \\
\text { - TGF } \beta \text { signaling: TGF } \beta \text { receptor signaling pathway, SMAD binding }\end{array}$ \\
\hline Hemoglobin, $\alpha[43]$ & - & - & & - Survival: positive regulation of cell death, oxygen transport \\
\hline
\end{tabular}


Table 1. Cont.

\begin{tabular}{|c|c|c|c|c|}
\hline Protein Name & $\begin{array}{c}\text { Change } \\
\text { AV }\end{array}$ & $\begin{array}{c}\text { Change } \\
\text { ML }\end{array}$ & $\begin{array}{c}\text { Change } \\
\mathrm{N}\end{array}$ & Molecular Functions and Biological Process \\
\hline Perlecan [43] & + & & & $\begin{array}{l}\text { - Protein processing and vesicular traffic: receptor-mediated } \\
\text { endocytosis } \\
\text { Extracellular matrix: extracellular matrix structural constituent } \\
\text { conferring compression resistance } \\
\text { Blood and blood vessel: angiogenesis } \\
\text { - General development: animal organ morphogenesis, tissue } \\
\text { development }\end{array}$ \\
\hline Internexin, $\alpha[43]$ & - & - & & $\begin{array}{l}\text { - Cytoskeleton: neurofilament and intermediate filament cytoskeleton } \\
\text { organization, postsynaptic actin cytoskeleton organization } \\
\text { - Nervous system: nervous system development, structural constituent } \\
\text { of postsynaptic actin } \\
\text { - General development: cell differentiation, multicellular organism } \\
\text { development }\end{array}$ \\
\hline
\end{tabular}

- $\quad$ Extracellular matrix: extracellular matrix structural constituent

- Cell adhesion: integrin binding, integrin-mediated signaling pathway, cell adhesion

Laminin, $\alpha 5$ [43] $\quad+\quad+$

- Nervous system: neural crest cell migration, axon guidance

- General development: animal organ morphogenesis, tissue development, regulation of cell migration

\begin{tabular}{|c|c|c|c|c|}
\hline Laminin, $\gamma 1$ [43] & + & + & & $\begin{array}{l}\text { - } \quad \text { Extracellular matrix: extracellular matrix structural constituent and } \\
\text { disassembly } \\
\text { - Cell adhesion: hemidesmosome assembly, cell adhesion } \\
\text { - } \quad \text { Nervous system: maintenance of blood-brain barrier } \\
\text { - General development: animal organ morphogenesis, tissue } \\
\text { development, cell migration }\end{array}$ \\
\hline $\begin{array}{l}\text { Lactadherin (medin } \\
\text { included) [43] }\end{array}$ & + & + & + & $\begin{array}{l}\text { - Protein processing and vesicular traffic: phagocytosis recognition, } \\
\text { engulfment, and positive regulation } \\
\text { - } \quad \text { Extracellular matrix: Extracellular matrix structural constituent } \\
\text { - } \quad \text { Bll adhesion: integrin binding, cell adhesion } \\
\text { Blood and blood vessel: angiogenesis }\end{array}$ \\
\hline $\begin{array}{l}\text { Smooth muscle myosin } \\
\text { heavy chain }[43]\end{array}$ & + & & & $\begin{array}{ll}- & \text { Cytoskeleton: actin binding } \\
-\quad & \text { Mucle contraction: calmodulin binding } \\
- & \text { Others: elastic fiber assembly, structural constituent of muscle }\end{array}$ \\
\hline $\begin{array}{l}\text { Neurofilament protein, } \\
\text { light polypeptide [43] }\end{array}$ & - & - & & $\begin{array}{l}\text { Cytoskeleton: microtubule cytoskeleton organization, neurofilament } \\
\text { bundle assembly, postsynaptic intermediate filament cytoskeleton } \\
\text { organization, neurofilament cytoskeleton organization } \\
\text { Nervous system: anterograde and retrograde axonal transport, axonal } \\
\text { transport of mitochondrion, hippocampus and cerebral cortex } \\
\text { development, negative regulation of neuron apoptotic process, neuron } \\
\text { projection morphogenesis, positive regulation of axonogenesis, axon } \\
\text { development }\end{array}$ \\
\hline Neurofilament 3 [43] & - & & & - Cytoskeleton: neurofilament bundle assembly \\
\hline Neurofascin [43] & - & - & & $\begin{array}{l}\text { - Cell adhesion } \\
\text { Nervous system: transmission of nerve impulse, axon guidance, } \\
\text { myelination, synapse organization }\end{array}$ \\
\hline $\begin{array}{l}\text { Leucine rich repeat } \\
\text { proteoglycans }[43]\end{array}$ & + & & & $\begin{array}{l}\text { - } \quad \text { Extracellular matrix: Extracellular matrix structural constituent } \\
\text { - Survival: Cell aging }\end{array}$ \\
\hline
\end{tabular}


Table 1. Cont.

\begin{tabular}{|c|c|c|c|c|}
\hline Protein Name & $\begin{array}{l}\text { Change } \\
\text { AV }\end{array}$ & $\begin{array}{l}\text { Change } \\
\text { ML }\end{array}$ & $\begin{array}{c}\text { Change } \\
\mathrm{N}\end{array}$ & Molecular Functions and Biological Process \\
\hline Solute carrier family 4 & - & & & $\begin{array}{l}\text { - Protein processing and vesicular traffic: transmembrane transport } \\
\text { - } \quad \text { Cytoskeleton: ankyrin binding } \\
\text { Blood and blood vessel: blood coagulation, hemoglobin binding }\end{array}$ \\
\hline Vinculin [43] & + & & & $\begin{array}{l}\text { - Protein processing and vesicular traffic: ubiquitin protein ligase } \\
\text { binding } \\
\text { Cytoskeleton: actin filament binding Cell adhesion: adherens junction } \\
\text { assembly, apical junction assembly, regulation of focal adhesion } \\
\text { assembly, epithelial cell-cell adhesion, regulation of protein } \\
\text { localization to adherens junction, beta-catenin binding, alpha-catenin } \\
\text { binding, cadherin binding } \\
\text { - Nervous system: axon extension } \\
\text { - General development: regulation of cell migration }\end{array}$ \\
\hline $\begin{array}{l}\text { Serum amyloid } \\
\text { P-component [44] }\end{array}$ & + & + & + & $\begin{array}{l}\text { - Others: negative regulation of glycoprotein metabolic process, } \\
\text { low-density lipoprotein particle binding }\end{array}$ \\
\hline TIMP3 [44] & + & + & & $\begin{array}{l}\text { - Protein processing and vesicular traffic: negative regulation of } \\
\text { membrane protein ectodomain proteolysis } \\
\text { - } \quad \text { Cell adhesion: negative regulation of ERK1 and ERK2 cascade } \\
\text { Others: metalloendopeptidase inhibitor activity }\end{array}$ \\
\hline VTN [44] & + & + & + & $\begin{array}{l}\text { - Protein processing and vesicular traffic: endocytosis, scavenger } \\
\text { receptor activity } \\
\text { Extracellular matrix: extracellular matrix structural constituent } \\
\text { - } \quad \text { Cell adhesion: cell-matrix adhesion, positive regulation of smooth } \\
\text { muscle cell migration, cell adhesion, integrin-binding } \\
\text { - General development: cell migration }\end{array}$ \\
\hline $\begin{array}{l}\text { Stromal cell-derived } \\
\text { factor } 1 \text { [44] }\end{array}$ & + & + & & $\begin{array}{l}\text { - } \quad \text { Cell adhesion: positive regulation of cell adhesion, integrin-binding } \\
\text { Blood and blood vessel: positive regulation of endothelial cell } \\
\text { proliferation } \\
\text { Nervous system: neuron migration, brain development, positive } \\
\text { regulation of neuron differentiation, positive regulation of axon } \\
\text { extension involved in axon guidance } \\
\text { Survival: response to hypoxia, negative regulation of intrinsic } \\
\text { apoptotic signaling pathway in response to DNA damage }\end{array}$ \\
\hline Chordin [44] & + & + & & $\begin{array}{l}\text { - } \quad \text { Cell adhesion: positive regulation of cell adhesion } \\
\text { - General development: negative regulation of cell migration }\end{array}$ \\
\hline Norrin [44] & + & + & & - Extracellular matrix: extracellular matrix-cell signaling \\
\hline Serine protease 23 [44] & + & + & & - $\quad$ Protein processing and vesicular traffic: proteolysis \\
\hline $\begin{array}{l}\text { High-temperature } \\
\text { requirement protein A1 } \\
\text { [44] }\end{array}$ & + & + & & $\begin{array}{l}\text { - Protein processing and vesicular traffic: serine-type endopeptidase } \\
\text { activity } \\
\text { - TGF } \beta \text { signaling: negative regulation of TGF } \beta \text { receptor signaling } \\
\text { pathway }\end{array}$ \\
\hline
\end{tabular}


Table 1. Cont.

\begin{tabular}{|c|c|c|c|c|}
\hline Protein Name & $\underset{\text { AV }}{\text { Change }}$ & $\begin{array}{c}\text { Change } \\
\text { ML }\end{array}$ & $\underset{N}{\text { Change }}$ & Molecular Functions and Biological Process \\
\hline $\begin{array}{l}\text { GCell adhesion: } \\
\text { lia-derived nexin [44] }\end{array}$ & + & + & & 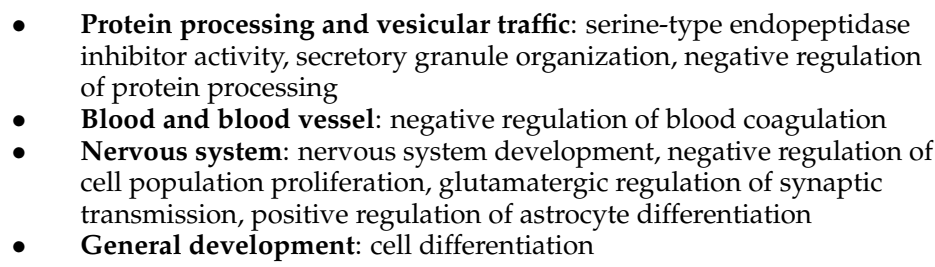 \\
\hline $\begin{array}{l}\text { Cell migration-inducing } \\
\text { and hyaluronan-binding } \\
\text { protein [44] }\end{array}$ & & + & & $\begin{array}{l}\text { - General development: positive regulation of cell migration } \\
\text { - Others: clathrin heavy chain binding }\end{array}$ \\
\hline Olfactomedin-like 3 [44] & + & + & & - General development: multicellular organism development \\
\hline $\begin{array}{l}\text { Collagen VIII } \alpha 1 \text { chain } \\
\qquad 44]\end{array}$ & & + & & $\begin{array}{l}\text { - Extracellular matrix: extracellular matrix structural constituent } \\
\text { structural constituent } \\
\text { - } \quad \text { Cell adhesion: cell adhesion } \\
\text { - Blood and blood vessel: angiogenesis }\end{array}$ \\
\hline $\begin{array}{l}\text { Microfibril-associated } \\
\text { glycoprotein } 4[44]\end{array}$ & & + & & $\begin{array}{l}\text { - Extracellular matrix: extracellular matrix structural constituent, } \\
\text { regulation of collagen metabolic process, elastic fiber assembly } \\
\text { - Cell adhesion: cell adhesion }\end{array}$ \\
\hline NOTCH3 [44] & + & + & + & $\begin{array}{l}\text { - Cell adhesion: cadherin binding } \\
\text { - } \quad \text { Gervous system: axon guidance } \\
\text { differentiation }\end{array}$ \\
\hline Annexin A2 [47] & & & + & $\begin{array}{l}\text { - Protein processing and vesicular traffic: positive regulation of } \\
\text { protein phosphorylation, negative regulation of endopeptidase activity, } \\
\text { negative regulation of catalytic activity, vesicle budding from the } \\
\text { membrane, positive regulation of vacuole organization, positive } \\
\text { regulation of vesicle fusion, positive regulation of receptor recycling } \\
\text { - Blood and blood vessel: angiogenesis } \\
\text { - } \quad \text { Extracellular matrix: collagen fibril organization } \\
\text { - Cell adhesion: cell-cell adhesion }\end{array}$ \\
\hline Periostin [47] & & + & + & $\begin{array}{l}\text { - } \quad \text { Survival: response to hypoxia } \\
\text { - Cell adhesion: negative regulation of cell-matrix adhesion; cell } \\
\text { - } \text { adhesion } \\
\text { Blood and blood vessel: regulation of systemic arterial blood pressure } \\
\text { - } \quad \text { Gotch signaling: regulation of Notch signaling pathway } \\
\text { - Smooth muscle: positive regulation of smooth muscle cell migration } \\
\text { - } \quad \text { Extracellular matrix: extracellular matrix organization, extracellular } \\
\text { matrix structural constituent } \\
\text { TGF } \beta \text { signaling: cellular response to transforming growth factor-beta } \\
\text { - } \quad \text { Nerimulus } \\
\text { Nervous system: neuron projection extension }\end{array}$ \\
\hline Complement C3 [47] & & & + & $\begin{array}{l}\text { - Protein processing and vesicular traffic: negative regulation of } \\
\text { endopeptidase activity, positive regulation of receptor-mediated } \\
\text { endocytosis, positive regulation of phagocytosis, engulfment, positive } \\
\text { regulation of apoptotic cell clearance } \\
\text { - } \quad \begin{array}{l}\text { Blood and blood vessel: positive regulation of vascular endothelial } \\
\text { growth factor production }\end{array} \\
\text { - Proteins related to Alzheimer's disease: amyloid-beta clearance } \\
\text { - Nervous system: neuron remodeling }\end{array}$ \\
\hline
\end{tabular}


Table 1. Cont.

\begin{tabular}{|c|c|c|c|c|}
\hline Protein Name & $\underset{\text { AV }}{\text { Change }}$ & $\begin{array}{c}\text { Change } \\
\text { ML }\end{array}$ & Change & Molecular Functions and Biological Process \\
\hline Plectin [47] & & - & + & $\begin{array}{l}\text { Cytoskeleton: Intermediate filament cytoskeleton organization, } \\
\text { actin-binding, ankyrin bindin } \\
\text { - Cell adhesion: hemidesmosome assembly, cadherin binding }\end{array}$ \\
\hline Biglycan [47] & & + & + & $\begin{array}{l}\text { - } \quad \text { Extracellular matrix: extracellular matrix structural constituent } \\
\text { - Blood and blood vessel: blood vessel remodeling }\end{array}$ \\
\hline Gelsolin [47] & & - & + & $\begin{array}{l}\text { - Protein processing and vesicular traffic: positive regulation of } \\
\text { cysteine-type endopeptidase activity involved in apoptotic signaling } \\
\text { pathway, regulation of receptor clusterin, positive regulation of protein } \\
\text { processing in the phagocytic vesicle, vesicle-mediated transport } \\
\text { - } \quad \text { Cytoskeleton: actin filament reorganization, actin-binding } \\
\text { - } \quad \text { Nell adhesion: regulation of cell adhesion } \\
\text { - } \quad \text { General develom: oligodendrocyte development } \\
\text { - Others: response to muscle stretch }\end{array}$ \\
\hline
\end{tabular}

Again, most of the molecular functions and biological processes (Gene Ontology) of these proteins are involved in cell adhesion processes, extracellular matrix components, angiogenesis, and the TGF $\beta$ signaling pathway.

As the HTRA1 protein was the most enriched protein, in this study, the authors analyzed its role in CADASIL. First, they proved that there was no mutation in HTRA1 DNA of CADASIL patients. Additionally, they found that the abundance of the protein did not correspond to differences between cases and controls in their mRNA, and that HTRA1 was located close to Notch3 deposits [46]. They also discovered that several of the proteins found in high numbers in CADASIL patients are substrates of HTRA1 (cell migrationinducing and hyaluronan-binding, olfactomedin-like 3, semaphorin 3G, and chordin), in addition to the already known substrates, such as VTN, an observation compatible with a reduction in its proteolytic activity [46].

Change AV (article of Arboleda-Velasquez et al. [43]), ML (article of Monet-Leprêtre et al. [44]), N (article of Nagatoshi et al. [47]): + in the case of a higher protein level in the samples of patients with CADASIL; - in the case of a lower protein level in samples from CADASIL patients compared with controls. Molecular functions and biological process: some of the molecular functions and biological processes from Gene Ontology for each protein. For a better understanding, we have grouped related terms together. Nagatoshi et al. used laser microdissection to collect GOM-enriched leptomeningeal arteries from two autopsied CADASIL patients and superficial temporal arteries from one biopsied CADASIL patient, and five controls [47]. Liquid chromatography-tandem MS showed that Notch3, serum amyloid P-component, annexin A2, and periostin, exhibited the largest increase [47]. Once again, our research on GO terms showed that most of the proteins detected by Nagatoshi et al. were involved in cell adhesion processes, cytoskeleton or extracellular matrix components, angiogenesis, or clearance.

Proteins from this study that were found in the article by Zellner et al. all followed the same direction, except for gelsolin and plectin. The histopathological analysis showed colocalization of serum amyloid P component and Notch3, predominantly in the tunica media of the vessels. ELISA analysis showed that serum amyloid P component biochemically binds to Notch3 dose-dependently, but not to Notch1 or Notch2 [47]. Interestingly, the expression study by RT-PCR with primers detecting serum amyloid P component in the liver showed low expression in both CADASIL patient samples and controls, suggesting that perhaps the marked reaction of its antibody in the cerebral vascular wall was due to cerebral synthesis. On the other hand, the authors found no difference between blood protein levels of serum amyloid P component between CADASIL patients and controls. The two other proteomic studies mentioned above $[43,44]$ showed the same direction of effect of serum amyloid $\mathrm{P}$ component, strengthening this result. 
Primo et al. generated a proteome using an aorta and blood taken from CADASIL mice with 53 angiogenesis-related proteins, pointing out that col18 $\alpha 1$ /endostatin could be a potential biomarker [48]. In addition, these authors explored the mice plasma levels of HTRA1 and Notch3 ECD as candidate biomarkers, finding an increase in the former and a decrease in the latter [48].

These studies discovered the presence of several proteins located next to NOTCH3, and this has allowed the in-depth study of the composition of GOMs, which are a hallmark of the disease.

\subsection{Transcriptomic Studies and Progress in the Etiopathogenesis of CADASIL}

A transcriptomic and proteomic study was performed on post-mortem brain material (frontal cortex and white matter) from two unrelated cases of CADASIL and five controls. With regard to changes in gene and protein expression, the authors found many terms related to RNA metabolism, such as RNA processing; RNA degradation; basal transcription; RNA polymerases; and spliceosome. In relation to energy metabolism, they found glycolysis; TCA cycle; oxidative metabolism and oxidative phosphorylation; impaired cell-cell interaction, such as extracellular matrix receptor interaction; tight junction; or cell adhesion molecules [49].

Frontal cortex and white matter shared terms, such as ribosome (upregulated genes); GPI-anchored biosynthesis; and ubiquitin-mediated proteolysis (downregulated genes); as well as leukocyte trans-endothelial migration and cell adhesion molecules (downregulated proteins) [49].

A transcriptomic study performed on skin biopsies (four cases paired with three healthy siblings) using microarray technology showed that the E2F4 gene was overexpressed in CADASIL patients [50]. Although this difference was not significant after correcting for multiple comparisons, the result was replicated in an independent sample of 10 new cases and 8 new controls by qRT-PCR.

E2F4 is expressed in endothelial cells and VSMCs as proved by the in situ hybridization performed [50]. This protein is associated with endothelial cell migration and involved in the process of intimal hyperplasia (IH) [51], which is the proliferation of VSMCs in the tunica media and their migration into the tunica intima of the vessel. E2F4 is also part of a complex containing Smad3, which acts as a transducer of TGF $\beta$ signals [50].

When performing an analysis of GO terms, a raw $p$-value under 0.01 was considered enriched since none of the analyses reached a significant $p$-value after correction for multiple comparisons. It is interesting to note that there is an observed growth in the network related to vascular development, catabolic and autophagy processes, vesicular machinery, and cell adhesion terms [50].

\subsection{Microbiome Studies and Progress in the Etiopathogenesis of CADASIL}

There is a single study that focuses on the analysis of the microbiome in CADASIL patients, where the gut microbiome of 15 Japanese CADASIL patients and 16 controls was evaluated [52]. CADASIL patients were divided according to whether they had suffered a symptomatic ischemic stroke $(n=7)$ or not $(n=8)$. There was no significant difference in vascular risk factors or nutritional items between CADASIL patients and the controls. The only significant difference was the daily intake of arachidonic acid between CADASIL subgroups, as patients with stroke had a lower intake $(p=0.03)$ [52].

A total of 790 operational taxonomic units (OTUs) was detected after the removal of singletons. No significant difference was observed in $\alpha$-diversity or $\beta$-diversity between CADASIL patients and the controls or between the patients with and without stroke [52].

In CADASIL patients compared with controls, there was a significant increase in abundance of the following: Lachnospira, Odoribacter, Parvimonas, unclassified genera belonging to Barnesiellaceae and Lachnospiraceae, unclassified genus belonging to order SHA-98; and a significant decrease in: Megasphaera and Acidaminococcus. Regarding the OTU level, CADASIL patients showed a significant increase in abundance of 24 OTUs and a significant 
decrease in 4 [52]. Between CADASIL subgroups, those with a stroke had a significant decrease in abundance of Phascolarctobacterium and Paraprevotella, a significant increase in abundance of 13 OTUs, and significant decrease in 3 OTUs [52].

The authors highlight some of these genera, such as Parvimonas, as they have been associated with ischemic stroke, or their abundance has been correlated with the amount of C-reactive protein in atherosclerotic patients. Moreover, Lachnospiraceae have been reported to stimulate IL-10 and TGF $\beta$ production [52].

Figure 4 shows a schematic summary of the molecules found in the -omics studies. Molecules found in at least two studies and with the same direction of effect have been considered.

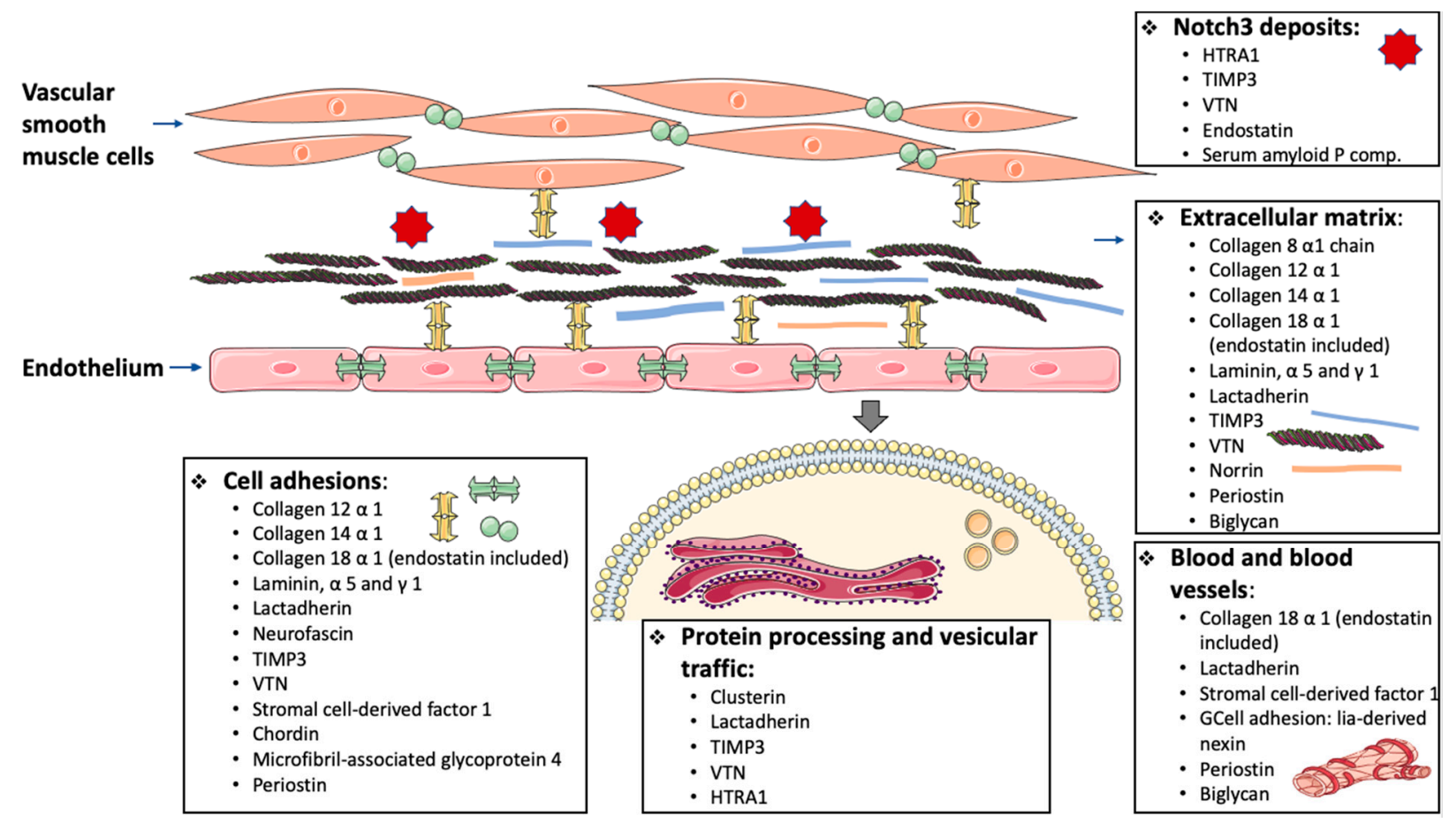

Figure 4. Schematic diagram of those molecules found in the -omics studies regarding its possible aetiopathogenic mechanism. Molecules found in at least two studies and with the same direction of effect have been considered. Graphic created through the smart.servier.com website.

\section{Genome-Wide Studies and Progress in Prognostic Assessment}

As previously mentioned, we do not have the tools for predicting the prognosis of CADASIL patients, as even monozygotic twins can progress differently [8,9].

Different markers have been found to be associated with the deterioration or survival of patients with CADASIL. Dementia and gait disturbance predict a higher degree of disability, whereas the number of lacunar and brain atrophies predict the clinical deterioration of patients with CADASIL [53], which, together with levels of neurofilament light chain, predict progression and survival [54].

A GWAS study conducted in 466 CADASIL patients to find an association with WMH volume did not find any GWAS-significant polymorphisms (SNP) [55]. Nevertheless, a polygenic risk score comprising all SNPs with a $p$-value $<0.5$ in the derivation sample was associated with $\mathrm{WMH}$ volume in the validation sample after correction for age, sex, and hypertension [55].

With these omics techniques, a high prevalence of carriers of pathogenic variants in NOTCH3 was found within cohorts that do not look at a specific phenotype [17-19].

This discovery was extremely important, as it showed that the mutational profile in these repositories was different from that of patients diagnosed with CADASIL. 
In 2016, Rutten et al. compared the mutations found in the exome aggregation consortium (ExAC) database and its update, the gnomAD, with the Dutch CADASIL registry (DCR) mutations (comprising 383 individuals with 45 different mutations from 163 families) [17]. They found that the distribution of Dutch CADASIL-causing NOTCH3 mutations overlapped with those reported worldwide, with most of these mutations affecting exon 4 (Figure 2) [17]. Meanwhile, in ExAC, mutations in exon 4 were three times lower, and mutations in exon 22 were 10 times higher than in the DCR [17].

The authors found that mutations in ExAC were mostly clustered in EGFr domains 14-16 and 29-31, whereas reported CADASIL mutations clustered in EGFr domains 1-6 [17]. The study in the gnomAD showed that $2.5 \%$ of the NOTCH3 mutations were in EGFr domains 1-6, whereas in European CADASIL patients, this percentage rose to $71.1 \%$ (Figure 5). Studying data from the UKB, $97 \%$ of the pathogenic NOTCH3 variants were found in EGFr domains 7-34 [19].

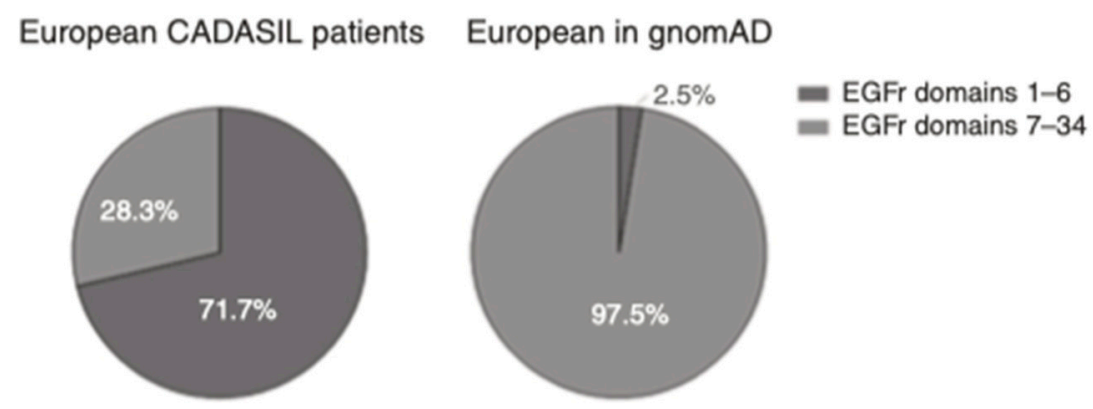

Figure 5. Location of NOTCH3 mutations in European CADASIL patients versus gnomAD database individuals. Figure extracted from Rutten et al. (2018) [18].

This led to the hypothesis that mutations outside EGFr domains 1-6, the classical CADASIL mutation location, predispose to a less severe phenotype [17].

Comparing patients with a mutation in EGFr domains 1-6 with patients with a mutation in EGFr domains 7-34 in the DCR, the former had an earlier diagnosis of the disease, a significantly higher WMH load, and a similar trend in the number of subcortical infarcts, and a first stroke at 55 years of age, with a mean survival time of 69 years (as opposed to patients with mutations in EGFr domains 7-34 who have their first stroke at the age of 67 and a mean survival time of 77 years) $[17,18]$.

Comparing individuals with NOTCH3 pathogenic variants with controls in the UKB $[19,20]$ and the Geisinger DiscovEHR [21], the authors found that subjects with pathogenic variants were correlated with spatial distribution (the anterior temporal lobe and external capsule) and extent of WMH, a higher frequency and number of lacunes and microbleeds, family history of stroke, and vascular dementia.

\section{Therapeutic Possibilities}

Due to the omics research carried out on CADASIL, several molecules with altered levels/expression have emerged, which could therefore be susceptible to pharmacological repositioning. Due to their relevance in the different studies, different authors have highlighted several molecules and studied them in-depth: Notch3, VTN, TIMP3, and Serum amyloid P-component. We have studied the possible treatments for pharmacological repositioning through DrugBank. For Notch3, endostatin, HTRA1, and E2F4 we have not found any available drugs. See Table 2. 
Table 2. Potential drugs for the targeted molecules found in omic studies. For Notch3, endostatin, HTRA1, E2F4, we have not found any available drugs.

\begin{tabular}{|c|c|c|}
\hline Target & Drug & Description \\
\hline VTN & Abciximab & $\begin{array}{l}\text { Fab fragment of the chimeric human-murine } \\
\text { monoclonal antibody 7E3. Abciximab binds } \\
\text { to the glycoprotein (GP) IIb / IIIa receptor of } \\
\text { human platelets and inhibits platelet } \\
\text { aggregation by preventing the binding of } \\
\text { fibrinogen, von Willebrand factor, and other } \\
\text { adhesive molecules. It also binds to the } \\
\text { vitronectin ( } \alpha \mathrm{v} \beta 3 \text { ) receptor found on } \\
\text { platelets and vessel wall endothelial and } \\
\text { smooth muscle cells }\end{array}$ \\
\hline
\end{tabular}

Others: copper, zinc, zinc acetate, chloride

Pimagedine has been developed by Synvista Therapeutics, Inc for the treatment of diabetic kidney disease. It is an advanced glycation

TIMP3 Pimagedine end-product inhibitor that manages diabetic nephropathy, either alone or in combination with other therapies. It is beneficial in treating patients with diabetic nephropathy.

Serum amyloid P-component

\author{
Methyl 4,6-O-[(1R)-1-carboxyethylidene]- \\ beta-D-galactopyranoside, \\ Bis-1,2-\{[(Z)-2-carboxy-2-methyl-1,3- \\ dioxane]-5-yloxycarbamoyl\}-ethane, \\ copper, zinc, zinc acetate, chloride
}

\title{
7. Limitations
}

The major limitation is that most of the studies were conducted on a very small number of patients, which limits the possibility of achieving statistically significant results adjusted for multiple comparisons. This may be partly due to the low frequency of the disease and its target tissue.

To overcome this low sample size, some authors performed studies directly in brain vessels, using sex- and age-matched subjects, or performed a similar analysis in animal models to support the findings observed. In fact, most of the molecules that overlapped in the different studies follow the same direction, supporting the findings. Moreover, in most studies, the molecules involved have common functions/pathways.

For the microbiome study, the sample size was small, and there was no replication study. The authors argue that even with small samples, other studies have reported robust evaluation of gut dysbiosis. The findings should nonetheless be taken with caution.

A limitation of the review processes used is that studies using omics other than the ones contained in the keywords may have been excluded. However, the studies with the highest volume of research for understanding CADASIL are in the field of genomics, transcriptomics, and proteomics.

\section{Discussion and Conclusions}

Due to the introduction of omics techniques in CADASIL studies, we have been able to gain insight into several aspects of the disease.

Nowadays, the diagnosis of CADASIL is more efficient, leading to a lower cost and time for analyzing more exons, which means that a larger number of patients can be screened in a more comprehensive way.

From an epidemiological point of view, we have gone from establishing a minimum CADASIL prevalence of 1.32-4.1/100,000 adults [14-16] to a prevalence of 1.4-3.4/1000 carriers of pathological variants in NOTCH3 [17-21] and 9/1000 in Taiwan [22]. 
Currently, comparing patients with a mutation in the EGFr domains 1-6 with patients with a mutation in EGFr domains 7-34 in the above-mentioned biobanks, subjects with pathogenic variants were correlated with spatial distribution (the anterior temporal lobe and external capsule) and extent of $\mathrm{WMH}$, a higher frequency and number of lacunes and microbleeds, family history of stroke, and vascular dementia [19-21].

This finding highlights the importance of the use of these technologies. The role of mutations considered pathogenic has been questioned. If they all produce CADASIL, then CADASIL is no longer a rare disease. Therefore, depending on the altered structural or functional domain, the patient could have a more or less torpid course. Another hypothesis is that perhaps not all pathogenic variants cause CADASIL. Since SNPs in the NOTCH3 gene were not found to be associated with lacunar stroke or WMH volume [56], maybe only the variants that affect the number of cysteines in EGFr are risk factors for developing small vessel disease, instead of CADASIL.

From the etiology perspective, omics techniques have made it possible to find molecules whose levels/expression are altered in patients with CADASIL, and which may be amenable to pharmacological repositioning. The most highlighted molecules by the authors in the articles were Notch3, HTRA1, TIMP3, VTN, endostatin, and serum amyloid P-component. The different studies showed that these proteins are co-localized with Notch3, supporting the etiopathogenic interest in them.

Mutations in HTRA1 are also the cause of small vessel cerebral arteriopathy in heterozygosis and homozygosis. In the latter case, they cause CARASIL (Cerebral Autosomal Recessive Arteriopathy with Subcortical Infarcts and Leukoencephalopathy), leading to TGF $\beta$ signaling impairment. TGF $\beta$ is closely related to small vessel disease in the brain [57]. The fact that several of the substrates of this enzyme are elevated in patients with CADASIL compared with controls, as in the case of VTN, suggests that its proteolytic activity may be diminished [46], as is the case of CARASIL [58].

The remaining molecules found in the proteomic studies, with the same direction of effect in at least two different studies, are likely to be of special interest in the disease. In fact, they have been related to angiogenesis, protein processing and vesicular trafficking, nervous system, or extracellular matrix, among others. To confirm their interest, targeted studies on these proteins would be of important value. Those proteins with contradictory effects in the studies reviewed may be false-positive associations and, therefore, should be taken with caution.

From transcriptomic studies, E2F4 has been found to be overexpressed in CADASIL patients, not knowing whether this elevated expression is due to a compensatory mechanism for lack of protein production or elevated levels of the protein.

E2F4 belongs to the E2F family of transcription factors. E2F members have been involved in neuronal migration, and activation of E2Fs in VSMCs promotes migration [59]. E2F4 is involved in the process of IH [51]. Mice lacking E2F4 exhibit increased IH following arterial damage [51].

Besides, a diminished expression of E2F4 attenuates the endothelial cell migration, and its subsequent overexpression could rescue normal endothelial migration [59].

Likewise, E2F4 is part of the signaling pathway of TGF $\beta$ [60]. As we have just mentioned, TGF $\beta$ is related to cerebral small vessel disease. On the one hand, mutations in HTRA1 produce a TGF $\beta$ signaling impairment and lead to the appearance of CARASIL. On the other hand, in CADASIL, HTRA1, and LTBP-1 (protein that regulates bioavailability of TGF $\beta$ [57]) are present in GOMs, the histopathological hallmark of the disease.

It is, therefore, important that all this information help us understand the reason for the alterations found in CADASIL, such as changes in cell adhesions and components of the extracellular matrix or angiogenesis, as well as highlighting other pathways that thus far only a few studies have considered, and which can be decisive, such as alterations in autophagy, mitochondria, or the TGF $\beta$ signaling pathway. This could encourage researchers to find drugs that could directly modify pathways that are clearly involved in CADASIL, instead of looking for drugs that target a specific molecule. 
Therefore, thanks to this vanguard technology, progress has been made in understanding the extent of the disease and its etiopathogenesis, but there is still a long way to go before we can fully comprehend what happens in CADASIL. Omic studies will allow further investigation of the etiopathogenesis of the disease in a cost-effective manner, since the costs of this type of technology are becoming increasingly lower, allowing the analysis of a larger number of patients and molecules at once, which with conventional techniques would entail a high expenditure of resources and time. In addition, it will allow the exploration of new working hypotheses in an unbiased manner and develop disease-modifying drugs in the future.

Author Contributions: Conception and design of the work: E.M., I.F.-C. and A.A.; writing-original draft preparation: E.M. and I.F.-C.; writing-review and editing: E.M., I.F.-C. and A.A. All authors have read and agreed to the published version of the manuscript.

Funding: This work was supported by a grant from the Instituto de Salud Carlos III (PI 11/0176), Generación Project, Maestro Project, INVICTUS+ network, Epigenesis Project (Marató de TV3), FEDER funds. E. Muiño is supported by a Río Hortega Contract (CM18/00198) from the Instituto de Salud Carlos III. I. Fernández-Cadenas is supported by a research contract from Miguel Servet Program (CP12/03298), from the Instituto de Salud Carlos III.

Institutional Review Board Statement: Not applicable.

Informed Consent Statement: Not applicable.

Acknowledgments: Special thanks to "Asociación CADASIL España" for their support.

Conflicts of Interest: The authors declare no conflict of interest.

\section{References}

1. Coto, E.; Menéndez, M.; Navarro, R.; García-Castro, M.; Alvarez, V. A new de novo Notch3 mutation causing CADASIL. Eur. J. Neurol. 2006, 13, 628-631. [CrossRef]

2. Opherk, C.; Duering, M.; Peters, N.; Karpinska, A.; Rosner, S.; Schneider, E.; Bader, B.; Giese, A.; Dichgans, M. CADASIL mutations enhance spontaneous multimerization of NOTCH3. Hum. Mol. Genet. 2009, 18, 2761-2767. [CrossRef]

3. Duering, M.; Karpinska, A.; Rosner, S.; Hopfner, F.; Zechmeister, M.; Peters, N.; Kremmer, E.; Haffner, C.; Giese, A.; Dichgans, M.; et al. Co-aggregate formation of CADASIL-mutant NOTCH3: A single-particle analysis. Hum. Mol. Genet. 2011, 20, $3256-3265$. [CrossRef]

4. Chabriat, H.; Vahedi, K.; Iba-Zizen, M.T.; Joutel, A.; Nibbio, A.; Nagy, T.G.; Krebs, M.O.; Julien, J.; Dubois, B.; Ducrocq, X. Clinical spectrum of CADASIL: A study of 7 families. Cerebral autosomal dominant arteriopathy with subcortical infarcts and leukoencephalopathy. Lancet 1995, 346, 934-939. [CrossRef]

5. Markus, H.S.; Martin, R.J.; Simpson, M.A.; Dong, Y.B.; Ali, N.; Crosby, A.H.; Powell, J.F. Diagnostic strategies in CADASIL. Neurology 2002, 59, 1134-1138. [CrossRef] [PubMed]

6. O'Sullivan, M.; Jarosz, J.M.; Martin, R.J.; Deasy, N.; Powell, J.F.; Markus, H.S. MRI hyperintensities of the temporal lobe and external capsule in patients with CADASIL. Neurology 2001, 56, 628-634. [CrossRef] [PubMed]

7. Rumbaugh, J.A.; LaDuca, J.R.; Shan, Y.; Miller, C.A. CADASIL: The dermatologic diagnosis of a neurologic disease. J. Am. Acad. Dermatol. 2000, 43, 1128-1130. [CrossRef] [PubMed]

8. Mykkänen, K.; Junna, M.; Amberla, K.; Bronge, L.; Kääriäinen, H.; Pöyhönen, M.; Kalimo, H.; Viitanen, M. Different clinical phenotypes in monozygotic CADASIL twins with a novel Notch3 mutation. Stroke 2009, 40, 2215-2218. [CrossRef]

9. Ceroni, M.; Poloni, T.E.; Tonietti, S.; Fabozzi, D.; Uggetti, C.; Frediani, F.; Simonetti, F.; Malaspina, A.; Alimonti, D.; Celano, M.; et al. Migraine with aura and white matter abnormalities: Notch3 mutation. Neurology 2000, 1869-1871. [CrossRef]

10. Horgan, R.P.; Kenny, L.C. 'Omic' technologies: Proteomics and metabolomics learning objectives: Ethical issues. Obstet. Gynaecol. 2011, 189-195. [CrossRef]

11. Orset, C.; De Grange, P.; Rousselet, E.; Ramsay, L.; Quill, M. Blood transcriptomic biomarker as a surrogate of ischemic brain gene expression. Ann. Clin. Transl. Neurol. 2019, 1681-1695. [CrossRef]

12. Chong, M.; Sjaarda, J.; Pigeyre, M.; Mohammadi-Shemirani, P.; Lali, R.; Shoamanesh, A.; Gerstein, H.C.; Paré, G. Novel drug targets for ischemic stroke identified through Mendelian randomization analysis of the blood proteome. Circulation 2019, 140, 819-830. [CrossRef]

13. Razvi, S.S.M.M.; Davidson, R.; Bone, I.; Muir, K.W. The prevalence of cerebral autosomal dominant arteriopathy with subcortical infarcts and leucoencephalopathy (CADASIL) in the west of Scotland. J. Neurol. Neurosurg. Psychiatry 2005, 76, 739-741. [CrossRef]

14. Narayan, S.K.; Kalaria, R.N. The minimum prevalence of CADASIL in northeast England. Neurology 2012, 32, 76-78. [CrossRef]

15. Moreton, F.C.; Razvi, S.S.M.M.; Davidson, R.; Muir, K.W. Changing clinical patterns and increasing prevalence in CADASIL. Acta Neurol. Scand. 2014, 130, 197-203. [CrossRef] [PubMed] 
16. Bianchi, S.; Zicari, E.; Carluccio, A.; Di Donato, I.; Pescini, F.; Nannucci, S.; Valenti, R.; Ragno, M.; Inzitari, D.; Pantoni, L.; et al. CADASIL in central Italy: A retrospective clinical and genetic study in 229 patients. J. Neurol. 2015, 262, 134-141. [CrossRef]

17. Rutten, J.W.; Dauwerse, H.G.; Gravesteijn, G.; van Belzen, M.J.; van der Grond, J.; Polke, J.M.; Bernal-Quiros, M.; Lesnik Oberstein, S.A.J.; Van Belzen, M.J.; Der Grond, V.; et al. Archetypal NOTCH3 mutations frequent in public exome: Implications for CADASIL. Ann. Clin. Transl. Neurol. 2016, 3, 844-853. [CrossRef]

18. Rutten, J.W.; Van Eijsden, B.J.; Duering, M.; Jouvent, E.; Opherk, C.; Pantoni, L.; Federico, A.; Dichgans, M.; Markus, H.S.; Chabriat, H.; et al. The effect of NOTCH3 pathogenic variant position on CADASIL disease severity: NOTCH3 EGFr 1-6 pathogenic variant are associated with a more severe phenotype and lower survival compared with EGFr 7-34 pathogenic variant. Genet. Med. 2018, 6-11. [CrossRef]

19. Rutten, J.W.; Hack, R.J.; Duering, M.; Gravesteijn, G.; Dauwerse, J.; Overzier, M.; van den Akker, E.B.; Slagboom, E.; Holstege, H.; Nho, K.; et al. Broad phenotype of cysteine altering NOTCH3 variants in UK Biobank: CADASIL to nonpenetrance. Neurology 2020, 95, e1835-e1843. [CrossRef]

20. Cho, B.P.H.; Nannoni, S.; Harshfield, E.L.; Tozer, D.; Gräf, S.; Bell, S.; Markus, H.S. NOTCH3 variants are more common than expected in the general population and associated with stroke and vascular dementia: An analysis of 200,000 participants. J. Neurol. Neurosurg. Psychiatry 2021, 1-8. [CrossRef]

21. Hack, R.J.; Rutten, J.W.; Person, T.N.; Li, J.; Khan, A. Cysteine-altering NOTCH3 variants are a risk factor for stroke in the elderly population. Stroke 2020, 3562-3569. [CrossRef]

22. Lee, Y.; Chung, C.; Chang, M.; Wang, S. NOTCH3 cysteine-altering variant is an important risk factor for stroke in the Taiwanese population. Neurology 2020. [CrossRef] [PubMed]

23. Meng, H.; Zhang, X.; Yu, G.; Lee, S.J.; Chen, Y.E.; Prudovsky, I.; Wang, M.M. Biochemical characterization and cellular effects of CADASIL mutants of NOTCH3. PLoS ONE 2012, 7, 1-13. [CrossRef]

24. Joutel, A. Pathogenesis of CADASIL: Transgenic and knock-out mice to probe function and dysfunction of the mutated gene, Notch3, in the cerebrovasculature. BioEssays 2011, 33, 73-80. [CrossRef]

25. Joutel, A.; Andreux, F.; Gaulis, S.; Domenga, V.; Cecillon, M.; Battail, N.; Piga, N.; Chapon, F.; Godfrain, C.; Tournier-Lasserve, E. The ectodomain of the Notch3 receptor accumulates within the cerebrovasculature of CADASIL patients. J. Clin. Investig. 2000, 105, 597-605. [CrossRef]

26. Ishiko, A.; Shimizu, A.; Nagata, E.; Takahashi, K.; Tabira, T.; Suzuki, N. Notch3 ectodomain is a major component of granular osmiophilic material (GOM) in CADASIL. Acta Neuropathol. 2006, 112, 333-339. [CrossRef] [PubMed]

27. Ueda, A.; Hirano, T.; Takahashi, K.; Kurisaki, R.; Hino, H.; Uyama, E.; Uchino, M. Detection of granular osmiophilic material of cerebral autosomal dominant arteriopathy with subcortical infarcts and leukoencephalopathy by light microscopy in frozen sections: Scientific correspondence. Neuropathol. Appl. Neurobiol. 2009, 35, 618-622. [CrossRef]

28. Ruchoux, M.M.; Maurage, C.A. Endothelial changes in muscle and skin biopsies in patients with CADASIL. Neuropathol. Appl. Neurobiol. 1998, 24, 60-65. [CrossRef]

29. Lewandowska, E.; Leszczyńska, A.; Wierzba-Bobrowicz, T.; Skowrońska, M.; Mierzewska, H.; Pasennik, E.; Członkowska, A. Ultrastructural picture of blood vessels in muscle and skin biopsy in CADASIL. Folia Neuropathol. 2006, 44, 265-273. [PubMed]

30. Ghosh, M.; Balbi, M.; Hellal, F.; Dichgans, M.; Lindauer, U.; Plesnila, N. Pericytes are involved in the pathogenesis of cerebral autosomal dominant arteriopathy with subcortical infarcts and leukoencephalopathy. Ann. Neurol. 2015, 78, 887-900. [CrossRef]

31. Okeda, R.; Arima, K.; Kawai, M. Arterial changes in cerebral autosomal dominant arteriopathy with subcortical infarcts and leukoencephalopathy (CADASIL) in relation to pathogenesis of diffuse myelin loss of cerebral white matter: Examination of cerebral medullary arteries by reconstruction of serial sections of an autopsy case. Stroke 2002, 33, 2565-2569. [CrossRef] [PubMed]

32. Brulin, P.; Godfraind, C.; Leteurtre, E.; Ruchoux, M.M. Morphometric analysis of ultrastructural vascular changes in CADASIL: Analysis of 50 skin biopsy specimens and pathogenic implications. Acta Neuropathol. 2002, 104, 241-248. [CrossRef]

33. Ruchoux, M.M.; Chabriat, H.; Baudrimont, M.; Tournier-Lasserve, E. Presence of ultrastructural arterial lesions in muscle and skin vessels of patients with CADASIL. Stroke 1994, 25, 2291-2293. [CrossRef] [PubMed]

34. Tikka, S.; Peng Ng, Y.; Di Maio, G.; Mykkänen, K.; Siitonen, M.; Lepikhova, T.; Pöyhönen, M.; Viitanen, M.; Virtanen, I.; Kalimo, H.; et al. CADASIL mutations and ShRNA silencing of NOTCH3 affect actin organization in cultured vascular smooth muscle cells. J. Cereb. Blood Flow Metab. 2012, 32, 2171-2180. [CrossRef] [PubMed]

35. Ruchoux, M.M.; Domenga, V.; Brulin, P.; Maciazek, J.; Limol, S.; Tournier-Lasserve, E.; Joutel, A. Transgenic mice expressing mutant Notch3 develop vascular alterations characteristic of cerebral autosomal dominant arteriopathy with subcortical infarcts and leukoencephalopathy. Am. J. Pathol. 2003, 162, 329-342. [CrossRef]

36. Haritunians, T.; Chow, T.; De Lange, R.P.J.J.; Nichols, J.T.; Ghavimi, D.; Dorrani, N.; St Clair, D.M.; Weinmaster, G.; Schanen, C.; St. Clair, D.M.; et al. Functional analysis of a recurrent missense mutation in Notch3 in CADASIL. J. Neurol. Neurosurg. Psychiatry 2005, 76, 1242-1248. [CrossRef] [PubMed]

37. Baron-Menguy, C.; Domenga-Denier, V.; Ghezali, L.; Faraci, F.M.; Joutel, A. Increased Notch3 activity mediates pathological changes in structure of cerebral arteries. Hypertension 2017, 69, 60-70. [CrossRef]

38. Hanemaaijer, E.S.; Panahi, M.; Swaddiwudhipong, N.; Tikka, S.; Winblad, B.; Viitanen, M.; Piras, A.; Behbahani, H. Autophagylysosomal defect in human CADASIL vascular smooth muscle cells. Eur. J. Cell Biol. 2018, 97, 557-567. [CrossRef] [PubMed]

39. Lewandowska, E.; Felczak, P.; Buczek, J.; Gramza, K.; Rafałowska, J. Blood vessel ultrastructural picture in a CADASIL patient diagnosed at an advanced age. Folia Neuropathol. 2014, 52, 443-451. [CrossRef] 
40. Viitanen, M.; Sundström, E.; Baumann, M.; Poyhonen, M.; Tikka, S.; Behbahani, H. Experimental studies of mitochondrial function in CADASIL vascular smooth muscle cells. Exp. Cell Res. 2013, 319, 134-143. [CrossRef]

41. Lewandowska, E.; Wierzba-Bobrowicz, T.; Buczek, J.; Gromadzka, G.; Dziewulska, D. CADASIL patient with extracellular calcium deposits. Folia Neuropathol. 2013, 51, 302-311. [CrossRef] [PubMed]

42. De La Peña, P.; Bornstein, B.; Del Hoyo, P.; Fernández-Moreno, M.A.; Martín, M.A.; Campos, Y.; Gómez-Escalonilla, C.; Molina, J.A.; Cabello, A.; Arenas, J.; et al. Mitochondrial dysfunction associated with a mutation in the Notch3 gene in a CADASIL family. Neurology 2001, 57, 1235-1238. [CrossRef]

43. Arboleda-Velasquez, J.F.; Manent, J.; Hyun, J.; Tikka, S.; Ospina, C.; Vanderburg, C.R.; Lee, J.H.; Tikka, S.; Ospina, C.; Vanderburg, C.R.; et al. Hypomorphic Notch 3 alleles link Notch signaling to ischemic cerebral small-vessel disease. Proc. Natl. Acad. Sci. USA 2011, 108, E128-E135. [CrossRef]

44. Monet-Leprêtre, M.; Haddad, I.; Baron-Menguy, C.; Fouillot-Panchal, M.; Riani, M.; Domenga-Denier, V.; Dussaule, C.; Cognat, E.; Vinh, J.; Joutel, A.; et al. Abnormal recruitment of extracellular matrix proteins by excess Notch3 ECD: A new pathomechanism in CADASIL. Brain 2013, 1830-1845. [CrossRef]

45. Capone, C.; Dabertrand, F.; Baron-Menguy, C.; Chalaris, A.; Ghezali, L.; Domenga-Denier, V.; Schmidt, S.; Huneau, C.; Rose-John, S.; Nelson, M.T.; et al. Mechanistic insights into a TIMP3-sensitive pathway constitutively engaged in the regulation of cerebral hemodynamics. Elife 2016, 5, 1-26. [CrossRef]

46. Zellner, A.; Scharrer, E.; Arzberger, T.; Oka, C.; Domenga-Denier, V.; Joutel, A.; Lichtenthaler, S.F.; Müller, S.A.; Dichgans, M.; Haffner, C. CADASIL brain vessels show a HTRA1 loss-of-function profile. Acta Neuropathol. 2018, 136, 111-125. [CrossRef]

47. Nagatoshi, A.; Ueda, M.; Ueda, A.; Tasaki, M.; Inoue, Y.; Ma, Y.; Masuda, T.; Mizukami, M.; Matsumoto, S.; Kosaka, T.; et al. Serum amyloid P component: A novel potential player in vessel degeneration in CADASIL. J. Neurol. Sci. 2017, 379, 69-76. [CrossRef] [PubMed]

48. Primo, V.; Graham, M.; Bigger-Allen, A.A.; Chick, J.M.; Ospina, C.; Quiroz, Y.T.; Manent, J.; Gygi, S.P.; Lopera, F.; D’Amore, P.A.; et al. Blood biomarkers in a mouse model of CADASIL. Brain Res. 2016, 1644, 118-126. [CrossRef]

49. Jenoe, P.; Bonati, L.; Engelter, S.; Lyrer, P. Combined transcriptomic and proteomic analyses of cerebral frontal lobe tissue identified RNA metabolism dysregulation as one potential pathogenic mechanism in cerebral autosomal dominant arteriopathy with subcortical infarcts and leukoencephalopathy (CADASIL). Curr. Neurovasc. Res. 2019, 478-490. [CrossRef]

50. Muiño, E.; Maisterra, O.; Balado, J.J.; Cullell, N.; Carrera, C.; Aguila, N.P.T.; Márquez, J.C.; Fabrega, C.G.; Lledós, M.; Sánchez, J.G.; et al. Genome-wide transcriptome study in skin biopsies reveals an association of E2F4 with cadasil and cognitive impairment. Sci. Rep. 2021, 1-12. [CrossRef]

51. Giangrande, P.H.; Zhang, J.X.; Tanner, A.; Eckhart, A.D.; Rempel, R.E.; Andrechek, E.R.; Layzer, J.M.; Keys, J.R.; Hagen, P.O.; Nevins, J.R.; et al. Distinct roles of E2F proteins in vascular smooth muscle cell proliferation and intimal hyperplasia. Proc. Natl. Acad. Sci. USA 2007, 104, 12988-12993. [CrossRef]

52. Matsuura, J.; Inoue, R.; Takagi, T.; Wada, S.; Watanabe, A.; Koizumi, T.; Mukai, M.; Mizuta, I.; Naito, Y.; Mizuno, T. Analysis of gut microbiota in patients with cerebral autosomal dominant arteriopathy with subcortical infarcts and leukoencephalopathy. $J$. Clin. Biochem. Nutr. 2019, 65, 240-244. [CrossRef]

53. Chabriat, H.; Hervé, D.; Duering, M.; Godin, O.; Jouvent, E.; Opherk, C.; Alili, N.; Reyes, S.; Jabouley, A.; Zieren, N.; et al. Predictors of clinical worsening in cerebral autosomal dominant arteriopathy with subcortical infarcts and leukoencephalopathy: Prospective cohort study. Stroke 2015, 4-11. [CrossRef]

54. Gravesteijn, G.; Rutten, J.W.; Verberk, I.M.W.; Böhringer, S.; Liem, M.K.; van der Grond, J.; Aartsma-Rus, A.; Teunissen, C.E.; Lesnik Oberstein, S.A.J. Serum neurofilament light correlates with CADASIL disease severity and survival. Ann. Clin. Transl. Neurol. 2019, 6, 46-56. [CrossRef] [PubMed]

55. Opherk, C.; Gonik, M.; Duering, M.; Malik, R.; Jouvent, E.; Hervé, D.; Adib-Samii, P.; Bevan, S.; Pianese, L.; Silvestri, S.; et al. Genome-wide genotyping demonstrates a polygenic risk score associated with white matter hyperintensity volume in CADASIL. Stroke 2014, 45, 968-972. [CrossRef] [PubMed]

56. Rutten-Jacobs, L.C.A.; Traylor, M.; Adib-Samii, P.; Thijs, V.; Sudlow, C.; Rothwell, P.M.; Boncoraglio, G.; Dichgans, M.; Bevan, S.; Meschia, J.; et al. Common NOTCH3 variants and cerebral small-vessel disease. Stroke 2015, 46, 1482-1487. [CrossRef] [PubMed]

57. Müller, K.; Courtois, G.; Ursini, M.V.; Schwaninger, M. New insight into the pathogenesis of cerebral small-vessel diseases. Stroke 2017, 48, 520-527. [CrossRef] [PubMed]

58. Nozaki, H.; Kato, T.; Nihonmatsu, M.; Saito, Y.; Mizuta, I.; Noda, T.; Koike, R.; Miyazaki, K.; Kaito, M.; Ito, S.; et al. Distinct molecular mechanisms of HTRA1 mutants in manifesting heterozygotes with CARASIL. Neurology 2016, 86, 1964-1974. [CrossRef]

59. Gu, L.; Hitzel, J.; Moll, F.; Kruse, C.; Malik, R.A.; Preussner, J.; Looso, M.; Leisegang, M.S.; Steinhilber, D.; Brandes, R.P.; et al. The histone demethylase PHF8 is essential for endothelial cell migration. PLoS ONE 2016, 11, 1-15. [CrossRef]

60. Chen, C.R.; Kang, Y.; Siegel, P.M.; Massagué, J. E2F4/5 and P107 as Smad cofactors linking the TGF $\beta$ receptor to c-myc repression. Cell 2002, 110, 19-32. [CrossRef] 